\title{
ADSORPSI LIMBAH PB MENGGUNAKAN APLIKASI CARBON NANO TUBE TERINTEGRASI DENGAN SISTEM LAHAN BASAH BANTARAN SUNGAI GAJAH WONG
}

\author{
Asih Melati $^{1, a),}$ Eka Sulistyawati $^{2, b}$, Ika Nugraheni ${ }^{3}$ \\ ${ }^{1}$ Physics Department UIN Sunan Kalijaga. ${ }^{2}$ Biology Department UIN Sunan Kalijaga

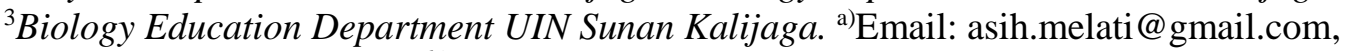 \\ ${ }^{b)}$ Email: eika_first@yahoo.co.id
}

\begin{abstract}
As a heavy polluted river in Yogyakarta, Gajah Wong River has been the target of Environment Agency (BLH) for its protection and water treatment program. Our preliminary

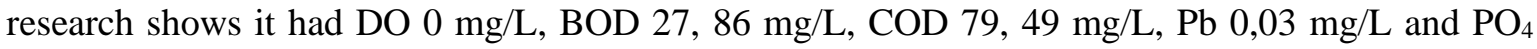
$3,250 \mathrm{mg} / \mathrm{L}$. The aim of this research was exploring the effectiveness of water treatment system using carbon nano tube based on coconut shells activated carbon integrated with wetland system. The Carbon nano tube was synthesized by using CVD methods while wetland system contains plants (which absorb pollutants. The result of this research are participated from Gajah Wong community and the water become more purify signed by BOD, DO, PO4 and COD normal value.
\end{abstract}

Key words: Pb, Carbon Nano Tube, BOD, DO, PO4, COD

\section{PENDAHULUAN}

Sungai Gajah wong merupakan bagian dari patahan sungai opak, dan lanjutan dari sungai boyong. Sungai gajah wong ini terletak di $7^{\circ} 49^{\prime} 26^{\prime \prime}-7^{\circ} 15^{\prime} 24$ dan $110^{\circ} 24^{\prime} 19^{\prime \prime}-110^{\circ}$ $28^{\prime} 53^{\prime \prime}$ E. sungai ini merupakan sungai yang menjadi sasaran target program prokasih (program kali Bersih) badan lingkungan hidup (blh) yogyakarta. Berita koran yang terbit dari Kedaulatan Rakyat yang terbit pada tanggal 6 April 2015 yang memberitakan resik resik sungai Gajah wong menjadi agenda rutin pemerintah kota Yogyakarta.

Berdasarkan hasil penelitian sebelumnya dan gerakan bersih sungai Gajah Wong yang telah dilakukan oleh Water Forum Sunan Kalijaga, diketahui bahwa Warga Desa Papringan banyak membuang limbah rumah tangga ke badan Sungai Gajah Wong yang berbatasan langsung dengan kampus UIN Sunan Kalijaga. Akibatnya air sungai Gajah Wong pada segmen ini memiliki karakter berwarna keruh, banyak sedimen, dengan parameter fisik dan kimia yang tidak memenuhi kriteria baku mutu. Selain itu, karakter utama sosio-ekonomi masyarakat ekonomi bawah, dengan banyaknya masyarakat yang bekerja sebagai pedagang, penambang pasir, dan pemulung menyebabkan kepedulian terhadap kualitas air sungai sangat rendah. Padahal, sebagian besar masyarakat bergantung pada air sungai untuk kebutuhan mandi, cuci, buang air besar dan kecil, serta kebutuhan produksi seperti pemasangan keramba untuk produksi lele. 


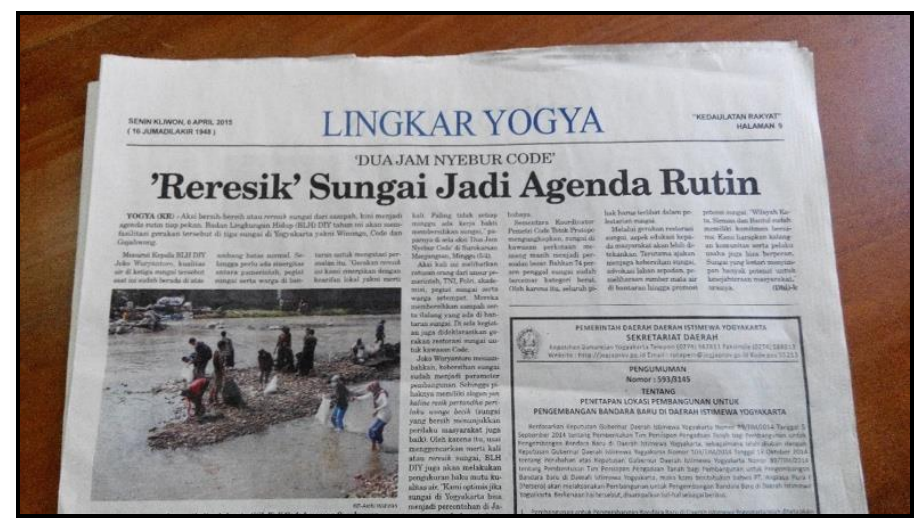

Gambar 1. Berita Koran KR 6 April 2015 tentang agenda rutin resik resik sungai Gajah Wong dan Code, mengingat limbah di sungai ini sangat memprihatinkan.

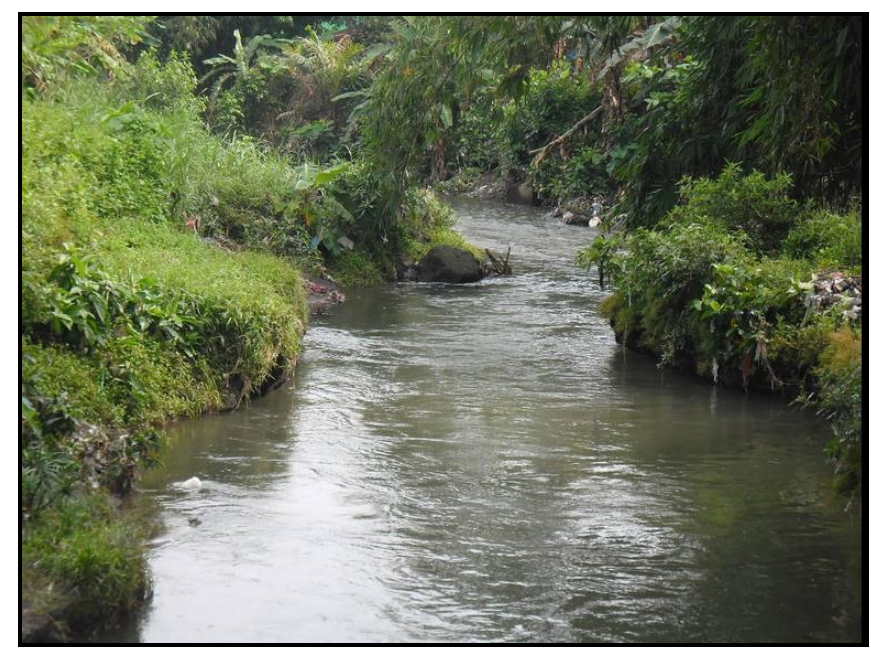

Gambar 1. Survey awal menunjukkan kondisi air sungai yang keruh karena banyak buangan limbah domestik dan rumah tangga yang masuk ke badan air

Berdasarkan penelitian yang dilakukan pada air Sungai ini positif terindikasi mengandung E.Coli berdasarkan metode Biakan teridentifikasi, BOD 3,416 mg/L dengan baku mutu $3 \mathrm{mg} / \mathrm{L}$ sehingga di luar Baku Mutu, DO 2,88 $\mathrm{mg} / \mathrm{L}$ dengan baku mutu 5 $\mathrm{mg} / \mathrm{L}$ sehingga di luar baku mutu. MPM Coliform $>1898 \times 10^{3} \quad$ metode IKM/5.4.1.M/BLK.Y dan Kandungan Fosfat $5,413 \mathrm{mg} / \mathrm{L}$ dengan baku mutu $0,2 \mathrm{mg} / \mathrm{L}$ di luar baku mutu serta berbagai uji lainnya meyatakan bahwa sungai Gajah Wong di daerah papringan yang padat penduduk ini di luar baku mutu standar sungai yang di syaratkan oleh Standar Baku Mutu Peraturan Gubernur DIY No 20. Th 2008. Dari penelitian sebelumnya (Syafaat 2012, Jane 2010, Sulityowati (2013) dan BLH (2012) limbah sungai Gajah Wong berasal dari (1) Limbah domestik dan limbah sampah padat (solid waste); (2) Toilet warga yang tidak memilki septi tank, sehingga air bercampur dengan feses langsung masuk ke sungai; (3) Bantaran sungai dijadikan sasaran TPS (tempat pembuangan sampah) 
ilegal (terdeteksi 11 TPS) dan (4) Banyak septi tank warga dialirkan ke sungai.

Air Sungai Gajah Wong mengalami pencemaran sehingga tidak dapat digunakan untuk keperluan rumah tangga, sanitasi, dan hygiene. Sedangkan di bantaran sungai Gajah wong sendiri masih banyak ditemukan aktivitas warga yang berhubungan langsung dengan pemanfaatan air sungai ini misalnya untuk keperluan mandi, cuci, dan buang air besar kecil serta serta rumah tangga yang dilakukan warga di bantaran sungai meskipun sungai telah mengalami pencemaran (Jane, 2010; Syafaat, 2012; Saptaningtyas, dkk, 2010).

Oleh karena itu diperlukan aplikasi teknologi untuk mengentaskan permasalahan ini. Dalam penelitian ini akan digunakan aplikasi teknologi yang ramah lingkungan yaitu Carbon Nano Tube yang disintesis dari tempurung kelapa dan terintegrasi dengan sistem lahan basah buatan. DIY Dalam Angka 2014 merilis bahwa kelapa merupakan komoditas terbesar nomor 3 yang dihasilkan oleh Daerah Istimewa Yogyakarta. Pada tahun 2013, kelapa berproduksi sebesar 55.752,70 ton atau turun 1,50 persen. Dari jumlah tersebut menghasilkan limbah $10 \%$ nya dari jumlah total sehingga menghasilkan limbah bathok kelapa sebesar 5575,27 ton untuk tahun 2013. Besarnya sampah bathok kelapa ini menjadi garapan tersendiri bagi pemerintah DIY, sehingga perlu untuk diperdayakan. Bathok kelapa akan di sintesis sehingga menjadi ukuran nano yang mampu menyerap limbah bahkan kuman, Limbah bathok kelapa diketahui memiliki potensi yang sangat besar untuk penjernihan air, terutama apabila telah dilakukan aktifasi terhadap batok kelapa tersebut sehingga berbentuk nano karbon. Dalam aplikasinya, pengabdian ini akan menambahkan teknologi lahan basah buatan (bioremidiasi) dengan memanfaatkan tanaman penyerap limbah. Tanaman penyerap limbah yang dimaksud berupa tanaman lokal yang ditemukan di sekitar Gajah Wong, berupa semanggi (Marsilea crenata), kangkung (Ipomoea sp), genjer (Limnocharis flava), dan kayu apu.
Carbon Nano Tube yang akan digunakan dalam penelitian ini merupakan material yang terbarukan, material ini mempunai molekul silinder yang lebar dilengkapi dengan pori-pori yang mampu mengikat limbah (Rassel, 2014). Molekul ini mempunyai susunan hexagonal $\mathrm{sp}^{2}$ carbon yang mengalami hibridisasi atom carbon yangmempunyai jarak C-C adalah $1,4 \AA$ Á. Dinding CNT ini terbagi menjadi dua yakni yang berputar dengan satu lembaran yang dinamain dengan single-walled carbon nanotubes (SWCNT) and berputar dengan lebh dari 1 lembaran yang dinamai are called multiwalled CNT (MWCNT). Kedua SWCNT dan MWCNT yang dibatasi pada kedua ujung tabung dalam susunan hemispherical jaringan karbon yang dinamai fullerene yang dibungkus dalam bentuk lembaran graphene. Pemisahan antar lapisan graphene MWCNT rerata jaraknya $0,34 \mathrm{~nm}$ dan masing-maisng lembaan mempunyai diameter $2.5 \mathrm{~nm}-200 \mathrm{~nm}$ (Zhang, 2011). Dengan diamtere yang lebih lebar dan bentuknya silender panjang dimungkinkan akan membuat limbah teradsorb dengan sempurna.

Tujuan penelitian ini adalah (1) Mensintesis carbon nano tube (CNT) yang berasal dari bahan alam tempurung kelapa; (2) Mendesain alat filter CNT yang terintegrasi dengan lahan basah buatan dan (3) Menguji keefektifan alat filter yang digunakan pada parameter $\mathrm{Ph}, \mathrm{DO}, \mathrm{BOD}, \mathrm{COD}, \mathrm{Pb}$ dan $\mathrm{PO}_{4}$. Ruang Lingkup penelitian adalah Sungai Gajah wong yang di treatment sepanjang $10 \mathrm{~m}$ dan pene;litian ini menggunakan Filter yang dibuat merupakan filetr yang ekonomis sehingga mampu dibuat sendiri oleh masyarakat. Manfaat Penelitian ini adalah (1) Menerapkan aplikasi nano teknologi dalam pengolahan limbah cair; (2) Menghasilkan produk alat filter limbah cair yang ekonomis dan (3) Mengetahui kefektifan CNT sebagai adsorben yang terintegrasi dengan lahan basah buatan.

\section{METODE PENELITIAN}

Langkah pertama yang dilakukan dalam penelitian ini adalah mensintesis CNT berbasis bahan alam tempurung kelapa dengan menggunakan metode chemical vapour 
deposition (CVD). Arang tempurung kelapa dipirolisis pada suhu $500^{\circ} \mathrm{C}$ kemudian arang yang terbentuk diaktivasi dan dilarutkan dalam benzene dan ferrocene dengan perbandingan 10:2 kemudian di pirolisis lagi menggunakan gas Argon selama 4 jam dengan suhu $700^{\circ} \mathrm{C}$. Setelah itu di netralisir dengan menggunakan $\mathrm{HNO}_{3} 65 \%$. Kemudian sampel yang terbentuk di karakterisasi dengan mengunakan SEM, XRD dan EDX. Setelah CNT terbentuk kemudian diintegrasikan dengan menambahkan epoxy resin pada sistem filtrasi lahan basah buatan yang sudah ditumbuhkan terlebih dahulu dalam sistem kolam di pinggir bantaran sungai. Grafik lengkap digambarkan dalam Gambar 3 dan Gambar 4.

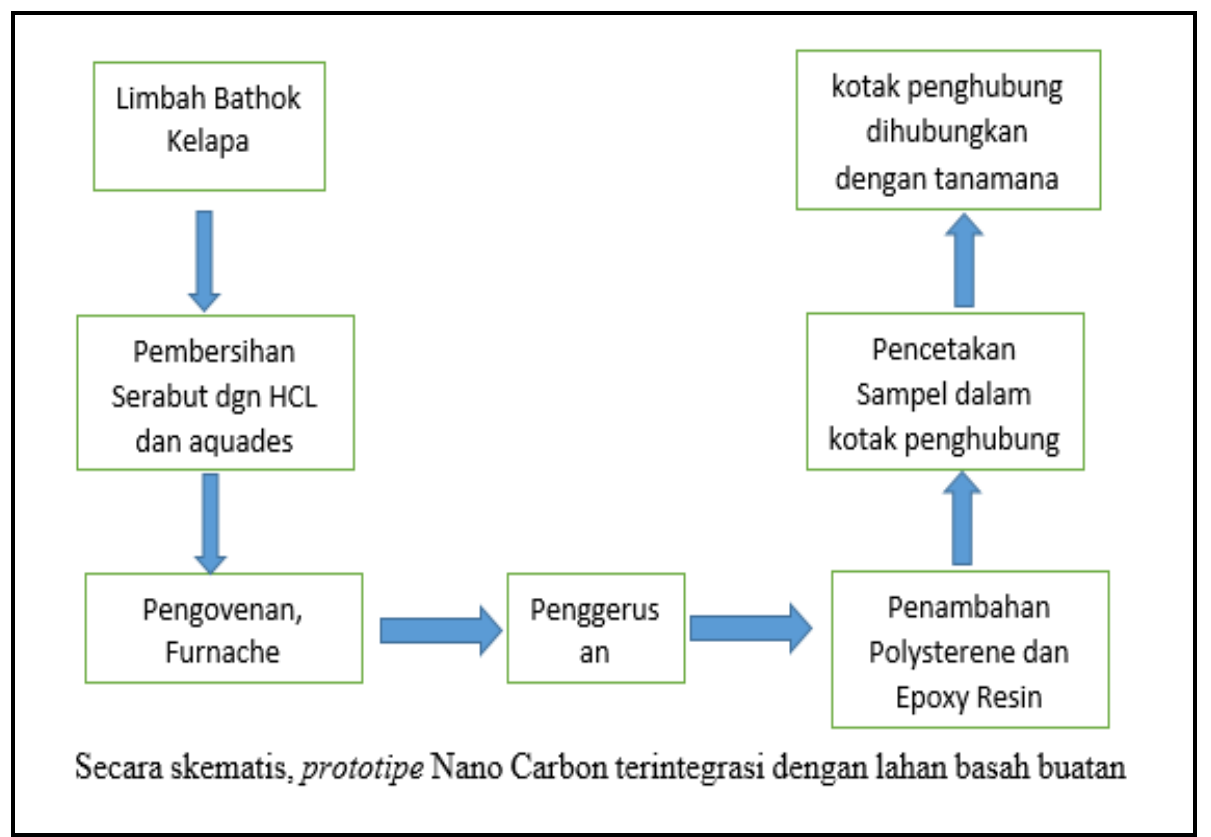

Gambar 3. Sintesis CNT dan pencetakan kotak penghubung

Sistem lahan basah buatannya aquatica L.) and Melati Air (basillus Sp) seperti menggunakan tanaman ar bambu air bagan yang di Gambar nomor 4 .

(Equisetum hyemale L.), Kangkung (Ipomea 


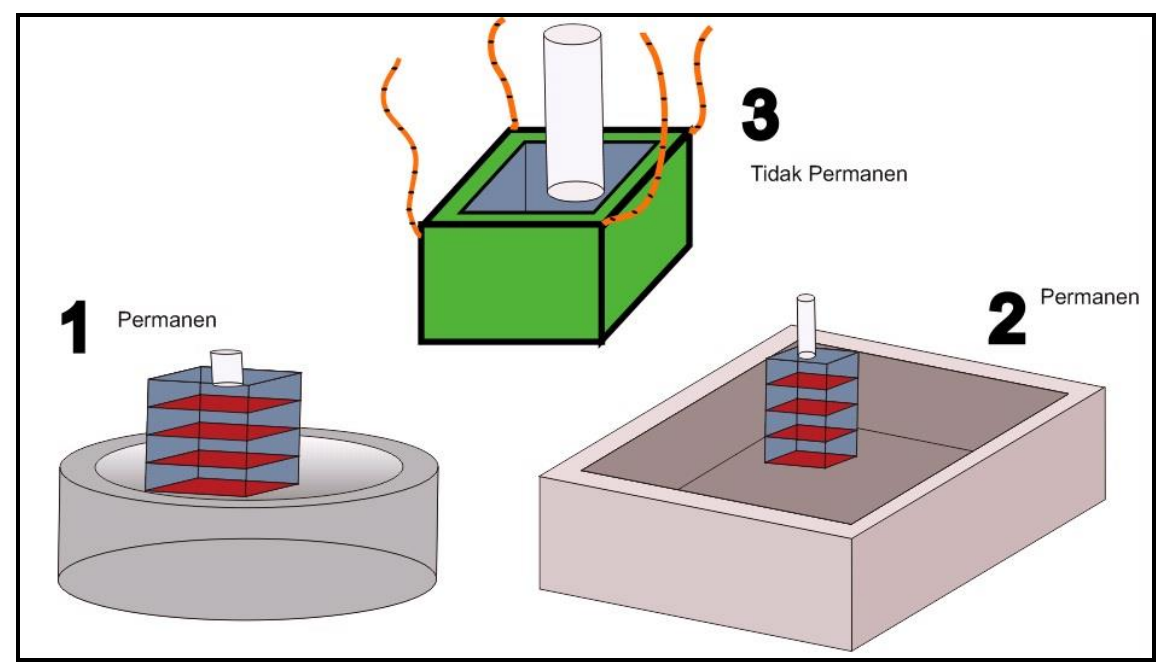

Gambar 5. Sistem filtrasi limbah yang terintegrasi dengan sistem lahan basah buatan

\section{HASIL DAN PEMBAHASAN}

\section{Hasil karakterisasi Carbon Nano Tube (CNT)}

Hasil karakterisasi material CNT menggunakan SEM (Scanning Electron Microscopy) material yang diperoleh berupa material Multi Wall Carbon Nano Tube (MWCNT) dengan ukuran $222 \mathrm{~nm}$ pada $\theta=30^{\circ}, 179 \mathrm{~nm}$ pada $\theta=83^{\circ}, 384 \mathrm{~nm}$ pada $\theta=62^{\circ}, 670 \mathrm{~nm}$ pada $\theta=5^{\circ} \mathrm{dan} 187 \mathrm{~nm}$ $\theta=72^{\circ}$. Material ini termasuk Multi Wall
Carbon Nano Tube (MWCNT) dikarenakan ukurannya lebih dari $100 \mathrm{~nm}$, walau begitu material ini masih termasuk material caron nano tube. Perbedaan mencolok antara jenis Multi Wall Carbon Nano Tube (MWCNT) selain ukurannya juga terlihat dari bentuknya yang bervariasi diameter tube nya.SEM diaatas Menggunakan SEM UIN Gunung Jati Bandung dengan perbesaran 2000x dengan $15 \mathrm{kV}$. Sedangkan karakterisasi menggunakan analisis EDX menunjukkan komponen yang terbesar nnao tube carbon sampai 340 gram (Gambar 7).

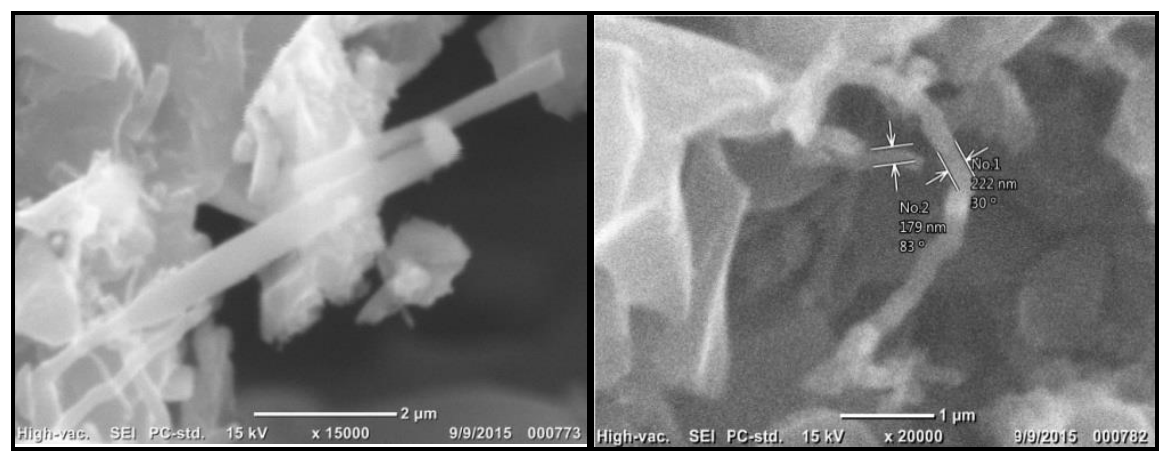

Gambar 6. Hasil Karakterisasi CNT menggunakan SEM 


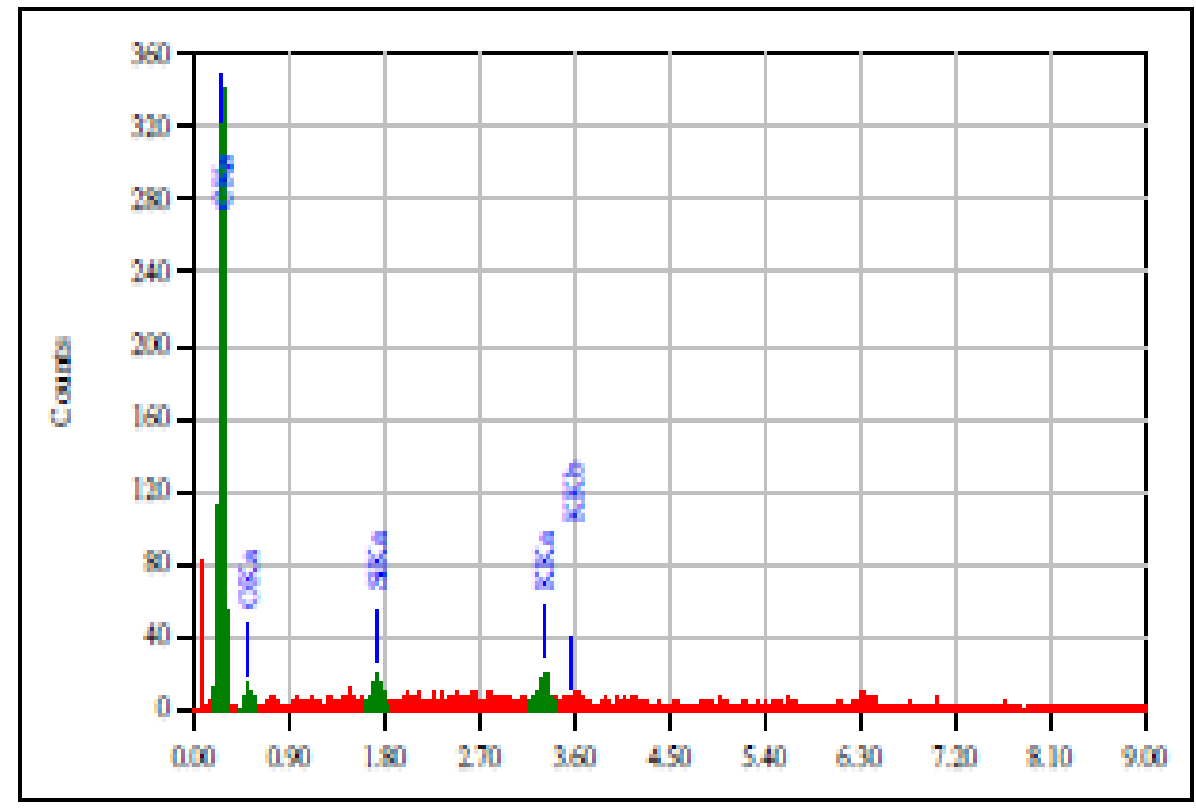

Gambar 7. Hasil Karakterisasi CNT menggunakan EDX

Tabel 1. Perbandingan komponen MWCNT dalam analisis EDX

\begin{tabular}{cccccccc}
\hline Element & $(\mathrm{KeV})$ & Mass (\%) & Counts & Sigma & $\mathrm{Mol}(\%)$ & Compound & Mass (\%) \\
\hline $\mathrm{C} \mathrm{K}$ & 0.277 & 92.08 & 1787.63 & 0.95 & 98.6 & $\mathrm{C}$ & 92.08 \\
$\mathrm{O} *$ & & 2.66 & & & & & \\
$\mathrm{Si} \mathrm{K}$ & 1.739 & 1.69 & 105.07 & 0.49 & 0.78 & $\mathrm{SiO}_{2}$ & 3.63 \\
$\mathrm{~K} \mathrm{~K}$ & 3.312 & 3.57 & 140.01 & 0.45 & 0.59 & $\mathrm{~K}_{2} \mathrm{O}$ & 4.30 \\
\hline
\end{tabular}

Dari Tabel 1 diatas terlihat bahwa komponen paling banyak adalah Carbon (C) dengan komposisi $92,08 \%$ dengan perhitungan teoritis (secara manual) didapatkan nilai yang tida jauh berbeda yaitu $93 \%$. Carbon terbentuk di kulit $\mathrm{K}$ artinya dengan energi yang rendah, dengan komposisi terbanyak kedua adalah $\mathrm{K}$ $(3,57 \%)$ dan kemudian Si (1,69\%). Keduanya berada di kulit $\mathrm{K}$ dengan energi yang terbesar adalah material $\mathrm{K}$ dengan energy $3.312 \mathrm{KeV}$ kemudian material Si. Kedua material ini muncul dikarenakan pada proses fungsionalisasi dan dari bahan gelas yang mungkin kurang bersih dalam pencucian.

\section{Rancang Bangun Filter Limbah air}

Langkah selanjutnya setelah sintesis nano carbon selesai dilakukan yakni pembuatan desain filter air. Dengan skema filterisasi air limbah yang berasal dari keluaran limbah rumah tangga seperti tertera dalam Gambar 7 dibawah ini. 


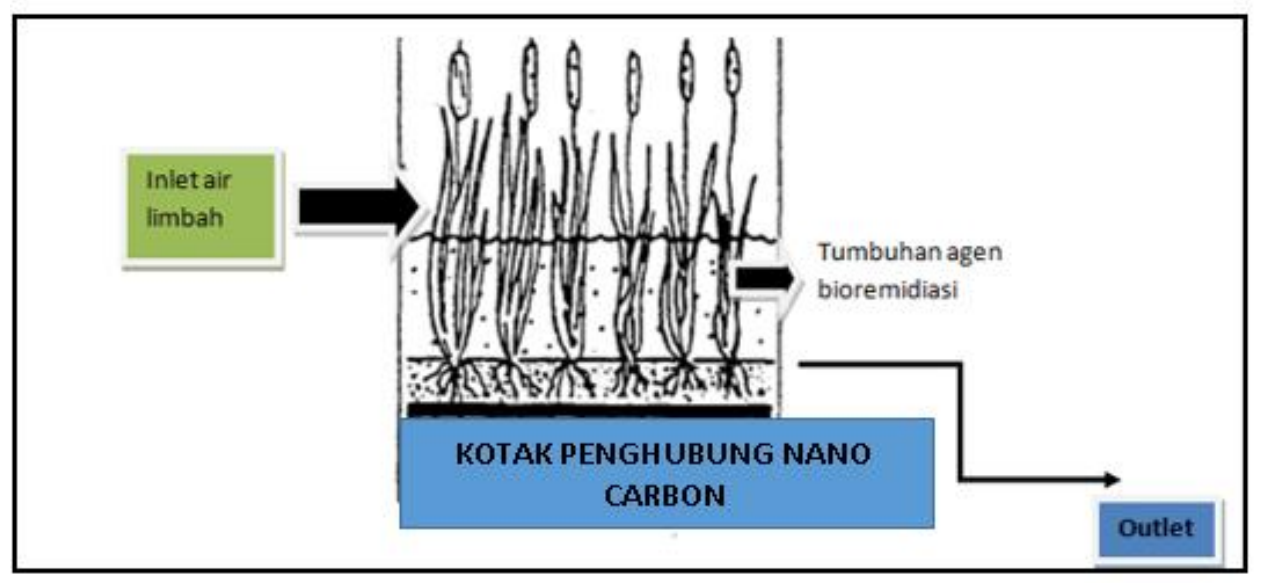

Gambar 7. Unit pengolah air sederhana yang dipasang di bantaran Sungai Gajah Wong

Sistem filterisasi mengggunakan Carbon Nano Tube yang terintegrasi dengan tumbuhan bioremidiasi. Bioremidiasi adalah nama lain system lahan basah buatan (Wetland System). Tanaman bioremidiadi perlu ditanam sebelumnya yaitu 2 minggu untuk tumbuh dan beradaptasi pada lingkungan sungai yang tercemar. Agen fitoremidiasi ini dipilih beberapa tanaman bioermidiasi yang mampu tumbuh dengan bagus di lingkungan sungai yaitu semanggi (Marsilea crenata), kangkung (Ipomoea sp), genjer (Limnocharis flava) serta Melati air (Mexican Swoth Plan). Tanaman tersebut dipilih bisa digunakan untuk pakan ternak sekaligus menumbuhkan keindahan karena Melati Air memiliki bunga yang lebar.

Lahan basah yang digunakan tersebut di cel secara rutin bagian batangnya. Batang yang besar memungkinkan menyerap limbah semakin bagus, dan bagian inilah yang mempunyai tingkta polutan yang tingg apabi sudah diterapkan sebagai adsorben. karena bagian batang yang membesar lebih banyak mengandung polutan, bagian ini tidak disarankan untuk dikonsmsi oleh manusia. Selanjutnya setelah berdiskusi dengan tokoh masyarakat setempat menggunakan sistem filtrasi bagan nomor 1 pada gambar nomor 5 diatas.

Sistem filtrasi reaktor ini ini dbuat sepanjang $100 \mathrm{~m}$ sungai Gajah Wong, flow reactor yang dipake merupakan model flow reaktor In situ, dimana sampel filtrasi dalam hal ini carbon nano tube ditaruh ditempatnya langsung, dan sampel material tidak dipindah. Setelah itu diendapkan selama 3 hari aga absorben mampu bekerja.. Dalam $100 \mathrm{~m}$ bantaran sungai dibangun 3 flow reactor. Setelah itu dilakukan uji kualitas air DO, BOD, $\mathrm{COD}, \mathrm{Ph}, \mathrm{Pb}$, dan bakteri E.coli yang megindiksikan keeradaan suspend penyakit diare. Pengujian dilakukan dengan 24 titik uji, dengan treatment 1 , treatment 2 dan inlet 1 dan outlet. 
Melati, E., Sulistyawati, E., \& Nugraheni, I. 2016. Adsorpsi Limbah Pb Menggunakan Aplikasi Carbon Nano Tube Terintegrasi dengan Sistem Lahan Basah Bantaran Sungai Gajah Wong. Journal of Sainstek 8(2): 104-112

Tabel 2, (a) tabel standar baku mutu air sungai b )flow reaktor dalam filtreasi limbah cair

\begin{tabular}{ll}
\hline \multicolumn{1}{c}{ Name of Testing } & \multicolumn{1}{c}{ Standard Quality } \\
\hline E.Coli & Negative \\
Water Ph & $6-9$ \\
DO & $5 \mathrm{mg} / \mathrm{L}$ \\
BOD & $75 \mathrm{mg} / \mathrm{L}$ \\
$\mathrm{PO}_{4}$ & $0,2 \mathrm{mg} / \mathrm{L}$ \\
$\mathrm{COD}$ & $200 \mathrm{mg} / \mathrm{L}$ \\
$\mathrm{Pb}$ & $0,03 \mathrm{mg} / \mathrm{L}$ \\
\hline
\end{tabular}

\begin{tabular}{llll}
\hline \multicolumn{1}{c}{ Uji Parameter } & \multicolumn{1}{c}{ Tanpa Treatment } & \multicolumn{1}{c}{ Treatment 1} & Treatment 2 \\
\hline E.Coli & Positive & Negative & Negative \\
Water Ph & 3 & 6 & 5.8 \\
DO & $0 \mathrm{mg} / \mathrm{L}$ & $0 \mathrm{mg} / \mathrm{L}$ & $0 \mathrm{mg} / \mathrm{L}$ \\
$\mathrm{BOD}$ & $27,86 \mathrm{mg} / \mathrm{L}$ & $152,72 \mathrm{mg} / \mathrm{L}$ & $150,20 \mathrm{mg} / \mathrm{L}$ \\
$\mathrm{PO}_{4}$ & $3,250 \mathrm{mg} / \mathrm{L}$ & $10,440 \mathrm{mg} / \mathrm{L}$ & $9,076 \mathrm{mg} / \mathrm{L}$ \\
$\mathrm{COD}$ & $79,49 \mathrm{mg} / \mathrm{L}$ & $153,60 \mathrm{mg} / \mathrm{L}$ & $168,96 \mathrm{mg} / \mathrm{L}$ \\
$\mathrm{Pb}$ & $0,0161 \mathrm{mg} / \mathrm{L}$ & $0,0141 \mathrm{mg} / \mathrm{L}$ & $0,0126 \mathrm{mg} / \mathrm{L}$ \\
\hline
\end{tabular}

Penelitian ini membandingkan harga dari kualitas air yang sesuai denga baku mutu. Dimana baku mutu ini mengacu ke kualitas suangai Gajah Wong yang termasuk kelas 2. Tabel baku mutu di tunjukkan di table nomor 2 (a). Dari data diatas dapat diketahui bahwa ssstem Flow Reactor dengan metode in situ aplikasi teknologi berbasis carbon nano tube yang di integrasikan dengan lahan basah buatan mampu meningkatkan penyerapan $\mathrm{Pb}$, menaikkan $\mathrm{Ph}$, walaupun untuk BOD mengalami kenaikan. Dalam hal ini integrasi Flow Reactor yang berisi carbon nano tube dan lahan basah buatan mampu menjadi filter yang mumpuni untuk masa depan.

\section{KESIMPULAN DAN SARAN}

Kesimpulan dalam penelitian ini adalah

1. Telah berhasil disintesis CNT dengan bentuk MWCNT dengan karakteristik ukuran paling rendah $179 \mathrm{~nm}$ dan dengan jumlah carbon $92,8 \%$

2. Telah dibentuk sistem filtrasi air terinttegrasi carbon nano tube berbasis bahan alam tempurung kelapa dengan lahan basah buatan kangkung dan melati air sebagai sistem filtrasi yang ramah lingkungan.

3. Setelah dilakukan uji filterasi flow reactor diperoleh adanay perubahan $\mathrm{Ph}$ yang membesar mengikuti ph netral, jumlah polutan $\mathrm{Pb}$ berkurang, walaupun untuk DO tidak mengalami perubahan dan BOD mengalami kenaikan. Untuk keberadaan bakteri E.Coli di satu treatment ada di sisi yang lain tidak ada.

\section{UCAPAN TERIMAKASIH}

Kami mengucapkan terimakasih yang sebesar-besarnya untuk dana hibah DIKTIS dengan SK Pengabdian Masyarakat No :5004 tahun 2015, water forum Kalijogo, Materials Physics study club UIN Sunan Kalijaga and Peduli Gajah Wong Community yang telah mensupport penelitian ini.

\section{DAFTAR KEPUSTAKAAN}

Anderson JC, JC Carlson, JE Low, CS Wong, JK Challis, CW Knapp, ML Hanson. 2013. Performance Of A Constructed Wetland In Grand Marais, Manitoba, Canada: Removal Of Nutrients, 
Pharmaceuticals, And Antibiotic Resistance Genes From Municipal Wastewater. Chemistry Central Journal , Vol. 7, p:54.

Badan Lingkungan Hidup (BLH) DIY. 2008. Kualitas Sungai Gadjah Wong Maret 2008.

Download http://blh.jogjaprov.go.id/ on 14 Mei 2012.

Chapman D .1992. Water Quality Assessments A Guide to Use of Biota, Sediments and Water in Environmental Monitoring. Second Edition. E\&FN Spon. Cambridge: The University Press.

D Rasel, dkk. 2014. Carbon Nanotube membrane for water purification: A bright future in water desalination, Elsavier, Desalination 336 :97-100.

Dix HM. 1981. Enviromental pollution. New York: John willey and Sons Inc.

DIY dalam Angka 2014, Pepmprop DIY

Eke E .2008. Hydrocarbon Removal with Constructed Wetlands. Disertasi. The University of Edinburgh.

Environmetal Protection Agency (EPA). 2013. A Handbook of Constructed Wetland. Volume 1. The USDA-Natural Resources Conservation Service.

Kirby J. 2013. Constructed Wetlands for Wastewater Treatment. Water Vol. 2, p: 530-549.
Knight RL, Clarke RAJr, Bastian RK. 2000. Surface flow (sf) treatment wetlands as a habitat for wildlife and humans. Water Science Technology 2000, Vol. 44, p: 27-38.

Min LC, Feng JZ, Won CO. 2009. Synthesis, characerization and photocatalytic analysis of $\mathrm{CNT}, / \mathrm{TiO} 2$ composits derived from MWCNT and Titanium sources, New Carbon material Journal Vol 24 No 2 Jun 2009 article ID 1007-8827 (2009) 02-0159-08.

Rampe MD, Bambang S, Wega dkk. 2011. Fabrication and characterization of carbon composites from coconut shell carbon, Indo J.Chem 11(2) 124-130.

Sears K, dkk. 2010. Recent Developments in Carbon Nanotube Membranes for water purification and Gas separation. Materials Journal, ISSN 1996-1944.

Woan K, Pyrgiotakis G, Sigmund W. 2013. Photocatalytic carbon-nanotube $\mathrm{TiO} 2$ Composites , jounal advanced material,www.admat.de.

Zhang et al. 2011. The application of Carbon nanotubes in target drug delivey system for cancer therapies, Nanoscale Research Letter, $6: 555$. 